UDC $347.77 / .78 ; 339.727 .22(497.11)$

CERIF: S124, S144

Nikola Ilić, LLM*

\title{
INTELLECTUAL PROPERTY RIGHTS AS FOREIGN DIRECT INVESTMENTS: CURRENT STATE OF AFFAIRS IN SERBIA**
}

This paper deals with the issue of whether intellectual property (IP) rights may be qualified as investments in terms of Serbian laws on investments, bilateral investment treaties (BIT) currently in force, and the ICSID Convention. The author first analyses the provisions of the Law on Investments with a special focus on the provisions defining an investment. By comparing these provisions with the corresponding norms of the previous law, as well as the relevant laws of the countries in the region, the enhanced solutions are highlighted, while the space for further improvement is identified. Subsequently, the author turns his attention to the applicable BITs and the ICSID Convention to examine whether IP rights may represent an investment under their terms. In the case of qualification of IP rights as investments, the right holders could be entitled to rely on the additional standards of legal protection and a new form of dispute settlement mechanism known as investment arbitration, while the host state could be exposed to a greater risk of being declared liable for breaches of legal standards and ordered to pay compensation to the investors. Upon analysing the main practical consequences of the qualification of IP rights, the author critically addresses major principles of the Serbian investment policy, which are identified through a detailed scrutiny of the relevant legal norms.

Key words: Intellectual property rights. - Foreign direct investments. - Law on investments. - Bilateral investment treaties. - ICSID Convention.

* Assistant Lecturer, University of Belgrade Faculty of Law, nikola.ilic@ius. bg.ac.rs.

** I wish to thank Ana Odorović, Andrea Radonjanin, Boris Begović, Bojana Todorović and Miloš Vukotić, for helpful comments and suggestions. Of course, the responsibility for any of the remaining errors and for the presented attitudes lies solely with the author. 
"Economic analysis enables intellectual property law to be grasped as a whole and the many commonalities among the different fields and cases to be seen clearly, along with the significant differences."

\section{INTRODUCTION}

In a globalised world, intellectual property (IP) rights should be strategically important for every market oriented economy. They are globally recognised as valuable assets, significantly contributing to the stock performance, revenue, and the business reputation of any given firm. In line with the state of affairs at the firm level, recent studies in the field of macroeconomics have revealed a noteworthy causal link between legal protection of IP rights, innovation, and economic growth. ${ }^{2}$

Probably the two most important characteristics of today's commerce could be seen in the: "[...] globalisation of economic activities and the expansion of international transactions involving knowledge-intensive products". ${ }^{3}$ In other words, commerce relies, to a great extent, on international investment law and intellectual property law, which are almost inseparably intertwined. The functional relationship between these two ubiquitous branches of law might be successfully examined in general terms. ${ }^{4}$ Yet, for practical purposes, specific legal rules in the relevant country have to be taken into account.

The legal qualification of IP rights as foreign direct investments (FDIs), under the domestic and international legal framework, might provide IP rights holders with additional legal protection and a new form of a dispute settlement mechanism, known as investment arbitration. ${ }^{5}$ Even

1 R. Posner, W. Landes, The Economic Structure of Intellectual Property Law, Harvard University Press, Cambridge, Massachusetts - London 2003, 420.

2 For further details, see: P. Welfens, Macro Innovation Dynamics and the Golden Age: New Insights into Schumpeterian Dynamics, Inequality and Economic Growth, Springer International Publishing, Cham 2017, 16-27, and D. Weil, Economic Growth, Pearson Education, Harlow 2013, 226-251.

3 C. Braga, C. Fink, "The Relationship between Intellectual Property Rights and Foreign Direct Investment”, Duke Journal of Comparative \& International Law 9/1998, 163.

4 For further details, see: L. Vanhonnaeker, Intellectual Property Rights as Foreign Direct Investments - from Collision to Collaboration, Edward Elgar Publishing, Cheltenham 2015, 9-37.

5 Investment arbitration is fundamentally different from commercial arbitration. While commercial arbitration is based on an arbitration agreement, investment arbitration may be based on the host state's national investment law, an investment treaty, either multi- or bilateral, or on an investment agreement. In commercial arbitration, the arbitral tribunal judges the contract between the parties, whereas in investment arbitration, the arbitral tribunal makes findings on the host state's behaviour towards a foreign investor. 
though this could have several positive consequences for the host state, such as more efficient technology transfer, reduction in IP piracy, and increase in FDI, such guaranteed additional protection could also mean greater exposure of the state in terms of its liability in the event of infringement of the established standards of legal protection. In practical terms, the key question is - can IP rights be qualified as an investment in accordance with the applicable investment law in Serbia, or not? And, if the answer to the first question is affirmative - what could be the main legal consequences and practical problems of such a qualification?

In order to provide answers to the raised questions, this paper will analyse various possibilities of qualifying IP rights as FDI under the Law on Investments (2) and the applicable bilateral investment treaties (BITs) in the Republic of Serbia (3). ${ }^{6}$ The qualification in accordance with the ICSID Convention will be examined separately (4), ${ }^{7}$ supported by the analysis of the main practical issues that could be noted in the event that IP rights are qualified as investments under the mentioned legal instruments (5). The concluding remarks will follow (6).

\section{IP RIGHTS AND THE LAW ON INVESTMENTS}

In 2015 the Serbian National Assembly adopted the new Law on Investments, which replaced the previous Law on Foreign Investments. ${ }^{8}$ The two main goals of the new Law were to enhance the investment environment in Serbia and to attract FDIs. ${ }^{9}$ In order to achieve the promulgated goals, the legislator introduced various forms of additional legal protection and economic incentives for future investors, from national treatment, protection against expropriation and full protection of the rights acquired based on an investment, to state aid and tax relief. Whether IP rights holders might enjoy the supplementary legal protection provided by the new legislation largely, depends on the definition of investment i.e. on the legal qualification of IP rights. ${ }^{10}$ In that sense, Article 3 of the Law on Investments introduces the following:

6 The Law on Investments, Official Gazette of the RS, No. 89/2015.

7 The Convention on the Settlement of Investment Disputes between States and National of other States, Washington DC, 18 March 1965 (hereinafter ICSID Convention).

8 The Law on Foreign Investments, Official Gazette of the FRY, No. 3/2002 and 5/2003, Official Gazette of the SCG, No. 1/2003 - Constitutional Charter, and Official Gazette of the RS, No. 107/2014 - other law. For further details on the history of investment legislation in the Republic of Serbia, see: V. Pavić, "Odlučnim polukorakom napred - osvrt na Zakon o ulaganjima", Anali Pravnog fakulteta u Beogradu 1/2016, 68-83.

9 See: Article 2 of the The Law on Investments.

10 Inconsistencies can be identified in the domestic legal system regarding the definition of investment. Namely, the Law on Investment is not the only legal source 
"an investment shall be:

$[\ldots]$

(d) intellectual property rights, protected under the applicable laws in the Republic of Serbia;

$[\ldots]^{\prime 11}$

This part of the definition might be seen as a significant improvement in comparison with the preceding Law on Foreign Investments. ${ }^{12}$ The most noticeable improvement may be in the explicit inclusion of IP rights, which better suits the underdeveloped domestic practice and could spare an investor (i.e. IP rights holder) the unnecessary burden of proof and complex legal hermeneutics when it comes to the interpretation of legal norms in a particular dispute. Additionally, the Law on Investments now explicitly provides an investor with the right to transfer incomes and royalties derived from intellectual property rights. ${ }^{13}$ However, several shortcomings of the new legislation may be noted as well. To begin with, the Law does not provide any additional requirements for IP right holders, such as transfer of funds or acquisition of IP rights for purposes of performing business activities in the host country, which is the case with real estate property rights. ${ }^{14}$ Although the lack of additional requirements might be seen as an enhancement from an investor's standpoint, it could be a shortcoming given that it might allow legal protection to those IP right holders that are not engaged in any investment activity in the host country. A straightforward example to that effect could be found in a case of an author of a movie or any other work of authorship. According to the Law on Copyright and Related Rights, a work of authorship is any author's original intellectual creation, and it is automatically protected by the law without any formal requirements, no matter where it was created. ${ }^{15}$ Strictly adhering to the Law on Investments, it could be argued that

containing the definition of investment. However, we find those inconsistencies irrelevant for the legal qualification of IP rights.

11 Article 3 (2) of The Law on Investments.

12 The Law on Foreign Investments did not explicitly include IP rights in Article 3 , which defined foreign investment. However, the preceding law did not completely exclude IP rights from the scope of legal protection. Article 3 and 6 The Law on Foreign Investments.

13 The previous Law on Foreign Investments provided "transfer of profit and dividends" acquired based on the investment, but it did not explicitly mention the transfer of royalties or any other incomes from IP rights. See: Article 12 of the The Law on Foreign Investments and Article 9 of the Law on Investments.

14 Article 3 (2) of the The Law on Investments.

15 Article 2 and 8 of the The Law on Copyright and Related Rights, Official Gazette of the RS, No. 104/2009, 99/2011, 119/2012 and 29/2016 - decision of the Constitutional Court. 
any author in the world would be able to enjoy the additional legal protection and initiate legal proceedings against Serbia alleging breaches of the Law on Investments. ${ }^{16}$ This issue, of course, is less conspicuous in the context of patents, trademarks, and other industrial property rights, which have to be acquired in a formal procedure before the competent authority. It could be assumed that it is, in fact, those industrial property rights that the legislator had in mind when defining the term investment.

Additionally, the Law on Investments provides for a "duty of authorities and urgency in treatment", granting investors "priority right" in front of any Serbian authority (with the exception of the Commission for Protection of Competition) with regard to the decision on any submitted request and issuance of a public document in administrative matters. ${ }^{17}$ Even putting aside the meaning of "priority right" in the domestic legal system, ${ }^{18}$ this provision could be quite challenging for the Intellectual Property (IP) Office of the Republic of Serbia. Until now, there seems to have been no clear indication that the IP Office regularly performs "priority duty", when it comes to the requests submitted by investors (in terms of the Law). Moreover, it could be disputable how this provision would interact with the provisions of relevant laws regulating acquisition of certain IP rights, which provide a special procedure for submission and decision on submitted requests before the competent authority. Thus, it might be advisable that the IP Office be excluded from the application of this provision together with the competition authority. ${ }^{19}$

16 The similar problem of too broad a definition of investment has been identified by domestic scholars with regard to the previous Law on Foreign Investments. See: N. Jovanović, "Pravni režim stranih ulaganja u Srbiju kao banana državu", Pravo i privreda 4-6/2013, 455-456; M. Jovanović, Odgovornost države za zažtitu stranih direktnih ulaganja, doctoral dissertation, Pravni fakultet Univerziteta u Beogradu, Beograd 2014, 163 164; Almost all of the exposed criticism has been incorporated into the new Law on Investments.

17 Article 16 of the The Law on Investments.

18 In the relevant laws dealing with industrial property, priority right is strictly defined and implies a completely deferent meaning. See: Article 89 of The Law on Patents, Official Gazette of the RS, No. 99/2011; Article 17 of the The Law on Trademarks, Official Gazette of the RS, No. 104/2009 and 10/2013; The Law on Legal Protection of Industrial Design, Official Gazette of the RS, No. 45/2015. For further details on the priority right: S. Marković, D. Popović, Pravo intelektualne svojine, Pravni fakultet Univerziteta u Beogradu, Beograd 2013, 123-126.

19 It is interesting that this "urgency clause" makes the Law on Investments unique in the region. The relevant laws in Slovenia, Croatia, Bosnia and Herzegovina, and Montenegro do not contain any similar provisions. See: The Foreign Exchange Act, Official Gazette of the Sl, No. 16/2008, 85/2009 and 109/2012; Zakon o poticaju ulaganja, Official Gazette, No. 102/2015; Zakon o stranim ulaganjima BIH, Official Gazette of the FBiH, No. 61/01 and 77/15; Zakon o stranim investicijama, Official Gazette of the MNE, No. 18/2011 and 45/2014; 
In addition to the mentioned novelties, the Law on Investments omitted a provision from the previous law providing more favourable treatment. ${ }^{20}$ In other words, it does not contain a particular provision for the case when bilateral or multilateral agreements signed by a foreign investor's country and the Republic of Serbia provide more favourable treatment for a foreign investor or its investment in comparison with the domestic law. Yet, this does not necessarily have to be qualified as a shortcoming of the new Law. The legal system should, in any event, be considered as a whole and the provisions of the Law on Investments should be interpreted together with the applicable provisions of bilateral and multilateral investment agreements. ${ }^{21}$

Finally, having in mind the stated goals of the enacted Law, it should be noted that the causal link between a protection of investments and an increase in FDI is strongly affected by the quality of the broader investment environment. IP rights are not a panacea and they may strengthen that causal link only to a certain degree, if used and analysed properly. IP rights are: "[...] an important component of the regulatory system, including taxes, investment regulations, production incentives, trade policies, and competition rules. Thus, from a policy perspective, it is the existence of a pro-competitive business environment that matters overall for FDI." 22 Therefore, analysing possibilities of qualifying and protecting IP rights as investments in accordance with the Law on Investments is only one of many missing puzzles. The next two closest puzzles to the explored are: a legal protection of IP rights in accordance with the applicable BITs and the ICSID Convention.

\section{IP RIGHTS AND APPLICABLE BITS IN SERBIA}

One of the acute problems closely related to the protection and enforcement of IP rights is the territorial limitation. Namely, while inventions and other intellectual creations protected by IP rights are easily transferable across borders and continents, IP rights are grounded in the domestic law of the particular state, and their legal effects are mainly limited to the national legal system. ${ }^{23}$ This separation between intellectual property rights and objects of protection is of crucial importance for

20 Article 13 of the Law on Foreign Investments.

21 This stance is in compliance with the Article 194 of the Constitution of the Republic of Serbia, Official Gazette of the RS, No. 98/2006.

22 E. Maskus, "Intellectual Property Rights and Foreign Direct Investment", Centre for International Economic Studies, Working Paper 22/2000, 2-3.

23 For further details on territorial limitation of IP rights, see: A. von Mühlendahl, D. Stauder, "Territorial Intellectual Property Rights in a Global Economy", MPI Studies on Intellectual Property, Competition and Tax Law, Springer, Berlin 6/2009, 653-673. 
foreign investors who are willing to commence a business in a given host country. To be more specific, such investors should be very much interested in the scope of legal protection and the effectiveness of legal enforcement in the host country. This might be seen as one of the major reasons why international agreements contain provisions dealing with IP rights. $^{24}$

The potential investor would, in many cases, have a strong incentive to check the possibilities for additional legal protection, which could be provided by BITs. From an investor's standpoint, the main goal of a BITis to provide additional protection and "assure foreign investors of access to an independent international tribunal in the event of a dispute between the host state and the foreign investor". ${ }^{25}$ Through the lens of an economist, which usually corresponds with the view of the host country, the main goal and the sole purpose of the BIT is to enhance investment environment and attract FDIs, even though the causal link between BITs and FDIs is quite weak and to a large degree affected by the institutional quality. ${ }^{26}$

As of 2017, Serbia has concluded 54 BITs, while 49 of them are in force. ${ }^{27}$ The first huge advantage foreign investors might gain from those

24 In that sense, the following quote is illustrative: "In order to bridge the gap between territorially limited IP rights and a globally integrated economy, various international treaties have been concluded [...]". J. Hosking, M. Perkams, "The Protection of Intellectual Property Rights Through International Investment Agreements: Only a Romance or True Love?", Transnational Dispute Management 2(5)/2009, 3.

25 S. Subedi, International Investment Law, Hart Publishing, Oxford 2008, 55-56.

26 For further details on the relationship between BIT and FDIs, see: J. Sasse, An Economic Analysis of Bilateral Investment Treaties, Springer, Hamburg 2011, 155-177.

27 Based on the succession rules, the BITs signed by the governments of the former Yugoslavia and the Serbia and Montenegro state union are binding for the Republic of Serbia. The BITs concluded with the following countries are currently in force: Albania (Official Gazette of the SCG-MU, No.10/042); Algeria (Official Gazette of the RS-MU, No. 05/2012); Austria (Official Gazette of the FRY-MU, No.01/02); Azerbaijan (Official Gazette of the RS-MU, No.8/11); Belarus (Official Gazette of the FRY-MU, No.04/96); Belgium (Official Gazette of the SCG-MU, No. 18/04); Bosnia and Herzegovina (Official Gazette of the FRY-MU, No. 12/02); Bulgaria (Official Gazette of the FRY-MU, No. 04/96); China (Official Gazette of the FRY-MU, No. 04/96); Croatia (Official Gazette of the FRY-MU, No. 10/01); Cyprus (Official Gazette of the SCG-MU, No.14/05); Czech Republic (Official Gazette of the RS-MU, No. 10/10); Denmark (Official Gazette of the $R S$-MU, No. 105/09); Egypt (Official Gazette of the SCG-MU, No.10/05); Finland (Official Gazette of the SCG-MU, No.10/05); France (Official Gazette of the SFRY, No.4/1975); Germany (Official Gazette of the SFRY, No.7/90); Ghana (Official Gazette of the FRY$M U$, No. 1/2000); Greece (Official Gazette of the FRY-MU, No. 02/98); Guinea (Official Gazette of the FRY-MU, No. 02/98); Hungary (Official Gazette of the SCG-MU, No.09/2004); India (Official Gazette of the SCG-MU, No.23/04); Indonesia (Official Gazette of the RS-MU, No.10/11); Iran (Official Gazette of the SCG-MU, No.02/05); Israel (Official Gazette of the SCG-MU, No.23/04); Kazakhstan (Official Gazette of the RS-MU, No. 3/11); DPR Korea (Official Gazette of the FRY-MU, No. 01/99); Kuwait (Official 
treaties is of a substantive legal nature - additional legal protection embodied in various legal standards, which are binding for the host country, such as: fair and equitable treatment, protection against expropriation, national treatment, etc. The second huge advantage is accessibility to additional dispute settlement mechanisms. Namely, the vast majority of applicable BITs provide three forums for the settlement of investment disputes, in addition to the domestic courts. That is also the case with Serbian Model BIT of 2007, which provides ad hoc arbitration under the Arbitration Rules of the United Nations Commission on International Trade Law, International Centre for the Settlement of Investment Disputes and the Court of Arbitration of the International Chamber of Commerce as additional forums. ${ }^{28}$

A more detailed analysis of the aforementioned advantages in the context of IP rights legal protection and enforcement will be conducted later in the paper. At this point, it is important to emphasise that in order to be additionally protected, IP rights, in the first place, must be subject to the legal qualification in accordance with the definition of investment, as provided by the applicable BIT. The vast majority of the concluded BITs contain a concise definition of an investment and IP rights are usually explicitly included. ${ }^{29}$

As a starting point in negotiations on a particular BIT, countries are usually inclined to impose provisions from their own Model BIT. In particular, in terms of a qualification of IP rights as the investment, representatives of Serbia could bear in mind a definition provided in Article 1 of the Serbian Model BIT, which reads:

"The term 'investment' shall mean every kind of assets directly invested by an investor of one Contracting Party in the territory of the

Gazette of the SCG-MU, No.2/05); Libya (Official Gazette of the SCG-MU, No.10/05); Lithuania (Official Gazette of the SCG-MU, No.10/05); Macedonia (Official Gazette of the FRY-MU, No. 05/96); Malta (Official Gazette of the RS-MU, No. 10/10); Montenegro (Official Gazette of the RS-MU, No. 01/10); Netherlands (Official Gazette of the SRJ-MU, No. 12/02); Nigeria (Official Gazette of the FRY-MU, No. 03/03); Poland (Official Gazette of the SRJ-MU, No. 06/96); Portugal (Official Gazette of the RS-MU, No. 01/10); Romania (Official Gazette of the FRY-MU, No. 04/96); Russia (Official Gazette of the $S R J$-MU, No. 03/95); Slovenia (Official Gazette of the SCG-MU, No. 06/04); Spain (Official Gazette of the SCG-MU, No. 03/04); Switzerland (Official Gazette of the SCG-MU, No. 03/06); Sweden (Official Gazette of the SFRJ, No.12/1979); Turkey (Official Gazette of the SRJ-MU, No. 04/01); Ukraine (Official Gazette of the FRY-MU, No. 04/01); United Arab Emirates (Official Gazette of the RS-MU, No. 1/2015-9); United Kingdom (Official Gazette of the SCG-MU, No. 10/04); The list of the applicable BITs is available at: $m t t$. gov.rs, last visited 25 June 2017.

28 See: Agreement between the Republic of Serbia and on Reciprocal Promotion and Protection of Investments, Article 9, http://mtt.gov.rs/, last visited 17 August 2017.

29 The only exceptions are the BITs concluded with the French Republic and the Kingdom of Sweden, from 1975 and 1979. 
other Contracting Party, in accordance with the laws and regulations of the latter and in particular, though not exclusively, shall include:

[...]

d) Intellectual property rights (such as copyrights and related rights, patents, industrial designs, trademarks) as well as goodwill, technical processes and know-how;

$[\ldots]^{\prime}, 30$

The Model BIT contains a broad definition of an investment, in terms of IP rights. ${ }^{31}$ Similarly to the Law on Investments, the Model BIT imposes no additional requirements for IP rights to be considered as investments, such as: transfer of funds, contribution to the host state development, etc. Moreover, the definition is even broader when compared to the Law since it includes also goodwill, technical processes, and knowhow. ${ }^{32}$ In relation to those categories, there could, however, be considerable risk that a foreign investor might be faced with probatio diabolica to demonstrate in front of a competent authority that its know-how or goodwill has been infringed or jeopardised. ${ }^{33}$

In summary, one might conclude that the Serbian Model BIT provides a definition of an investment (in terms of IP rights) which is too broad. The same conclusion could be reached in relation to the vast majority of the BITs currently in force. The only question that remains is whether extensive legal protection is beneficial for the domestic investment environment. It seems, in this case, that the higher degree of nominal protection does not necessarily improve the effective legal protection. On the contrary, a too broad definition of investment, contained in the applicable BITs, in combination with relatively undeveloped legal practice, might be the cause of legal uncertainty and needless disputes, and might actually discourage investors from investing in the host country.

30 Article 1 (2) of the The Serbian Model BIT.

31 The problem of too broad a definition of investment in BITs has been identified by domestic scholars. See: V. Draškoci, "Problem preširoke definicije pojma investicije u dvostranim sporazumima o međusobnom podsticanju i zaštiti ulaganja između Srbije i stranih država", Pravo i privreda 5-8/2007; M. Jovanović, 166-177.

32 It is interesting that the BIT concluded with Albania, in addition to IP rights and know-how, explicitly qualifies a license as the investment. See: Article 1 (2) (d) of the BIT.

33 Know-how is not an intellectual property right but the factual relationship. It is the same case with goodwill and technical processes. For further details on delineation between know-how and IP rights, see: S. Marković, D. Popović, 305-309. 


\section{IP RIGHTS AND THE ICSID CONVENTION}

The BITs applicable in Serbia usually provide more than one dispute settlement mechanism. However, the ICSID could be seen as the most common and the only specialised forum in the field of international investment law. ${ }^{34}$ That is the primary reason why the legal qualification of IP rights under the ICSID Convention will be analysed separately.

The Republic of Serbia ratified the ICSID Convention in 2007, which is a crucial precondition for an investment dispute to be adjudicated before the ICSID. The additional prerequisites for activation of the dispute resolution mechanism are consent of the parties, the parties' legal status, and a legal nature of a dispute ${ }^{35}$ Following those procedural issues, the tribunal in a particular case needs to closely investigate whether the object of a dispute might be qualified as an investment or, in other words, whether the jurisdiction ratione materiae may be established.

The ICSID Convention undoubtedly contains the term investment, yet it does not contain the substantial definition of the term. ${ }^{36}$ Thus, in legal practice, an economic point of view has been commonly accepted, according to which, an investment might involve five elements: 1) a transfer of funds, 2) a long-term project, 3) a purpose of regular income, 4) a participation of the person transferring funds, and 5) an element of risk. ${ }^{37}$ The same stance has been adopted and confirmed in several cases, including Salini v. Morocco and Biwater v. Tanzania. ${ }^{38}$ Based on the Convention's preamble, the Salini tribunal has established one additional element that has to be considered -6) contribution to the host state develop-

34 One of the main reasons for such a state of affairs may be found in the member states' contractual obligation to implement ICSID awards equally as judgements by their own courts, without any special legal procedure related to the recognition and enforcement of the award. See: Article 54 of the ICSID Convention; for more details on recognition and enforcement of arbitral award see: G. Knežević, V. Pavić, Arbitraža i ADR, Pravni fakultet Univerziteta u Beogradu, Beograd 2013, 172-183.

35 For further details on prerequisites for activation of the dispute resolution mechanism see: M. Stanivuković, "Rešavanje sporova koji proističu iz stranih ulaganja", Pravni život 12/97, 229-245.

36 Article 25 of the ICSID Convention provides the following: "The jurisdiction of the Centre [ICSID] shall extend to any legal dispute arising directly out of an investment, between a Contracting State [...] and a national of another Contracting State, which the parties to the dispute consent in writing to submit to the Centre."

37 See: R. Dolzer, C. Schreuer, Principles of International Investment Law, Oxford University Press, Oxford 2012, 60-61; A. Grabowski, "The Definition of Investment under the ICSID Convention: A Defense of Salini”, Chicago Journal of International Law 15/2014, 287-309; L. Vanhonnaeker, 24-28.

38 ICSID Case No. ARB/00/4, Salini et al. v. Kingdom of Morocco, Decision on Jurisdiction, para. 52; ICSID Case No. ARB/05/22, Biwater Gauff Ltd. v. United Republic of Tanzania, Award, para. 316. 
ment. ${ }^{39}$ Still, it is a prevailing standpoint that the contribution does not have to be measurable and it "should include development of human potential, political and social development, and the protection of the local and the global environment." 40

Concerning the IP rights, it appears that they could be qualified as an investment under the terms of the Convention. ${ }^{41}$ The creation of intellectual goods and subsequent investments in the acquisition of IP rights, their maintenance, licensing and enforcement, are usually not possible without the transfer of funds and long-term performances. Additionally, all the various forms of "IP rights' management" could generate considerable financial risk, especially when it comes to the enforcement. Therefore, these three preconditions (the transfer of funds, long-term performances, and business risk) could be met in a majority of IP rights' cases. The regularity of income might be difficult to satisfy, especially bearing in mind that the value of IP rights depends on many factors, including various conditions in the relevant market. ${ }^{42}$ It is not rare that some IP rights simply do not provide the rights holders any income, due to the existence of a better and cheaper products on a relevant market, or simply because of the absence of the initially forecasted demand. Moreover, the regularity of income might, to a certain extent, predetermine fulfillment of the remaining preconditions (the participation in management and the contribution), given that IP rights without market value probably are neither worthy of a substantial commitment, nor contribute to the host state development. However, if the regularity of income is evident, it could be argued that the remaining preconditions are met.

The issue that could be even more challenging is a legal qualification of pre-investment activities as an investment. For instance, in a case when an entity has actively fulfilled all preconditions for creation of a new medicine or a movie in a host country, would it be possible to qualify those pre-investment activities as the investment, in the meaning of Article 25 of the ICSID Convention? If relying solely on existing ICSID case law, the answer would be probably negative. In the Mihaly v. Sri Lanka case, the tribunal found that: "The Claimant has not succeeded in furnishing any evidence $[. .$.$] that pre-investment and development expen-$

39 Salini et al. v. Morocco, para. 52.

40 C. Schreuer et al., The ICSID Convention: A commentary, Cambridge University Press, Cambridge 2009, 133-134.

41 The qualification of IP rights under the terms of the ICSID Convention, in accordance with the stances of the established case law, does not prejudice (and should be distinguish from) legal qualification in a particular case.

42 For further details on the valuation of IP rights, see: L. Russell, G. Smith, Intellectual Property: Valuation, Exploitation, and Infringement Damages, Wiley, Hoboken 2005, 140-254; M. Federico, R. Oriani (eds.), The Economic Valuation of Patents: Methods and Applications, Edward Elgar Publishing, Cheltenham 2011, 109-205. 
ditures in the circumstances of the present case could automatically be admitted as "investment" [...]"43 Moreover, the negative attitude toward the same question has been taken in the three later cases, Zhinvaliv. Georgia, PSEG v. Turkey and Generation Ukraine v. Ukraine. ${ }^{44}$ A similar stance has been adopted in legal theory: "[...] pre-investment activities might become a part of the overall investment and thus be protected, only if the project started with realisation." 45 In line with the existing case law and theory, it would be hard to argue that pre-investment activities related to the acquisition of IP rights could be qualified as an investment in accordance with the ICSID Convention. Yet, it seems that those activities might be qualified as part of some other investment, within a project whose implementation has already started.

\section{NOTED PRACTICAL ISSUES}

Due to the lack of the relevant arbitral practice, it could be difficult to predict all the possible practical consequences of legal qualification of IP rights in accordance with the applicable investment law in Serbia. Yet, some conclusions might be reached from the international arbitral practice, which has already taken the stance that IP rights may be qualified as investments in accordance with the relevant legal instruments.

For example, in the recently concluded case Fillip Morris v. Uruguay, the ICSID tribunal qualified trademark as an investment, based on the BIT concluded between the Swiss Confederation and the Oriental Republic of Uruguay. ${ }^{46}$ In this case, the Government of Uruguay introduced various regulatory measures affecting the cigarettes market, including those imposing bans on selling different types of presentations of the same brand of cigarettes, advertising, smoking in public places (such as offices, student centres, restaurants, etc.), introducing higher taxes and prescribing mandatory warning images that were to cover at least $80 \%$ of the cigarette pack. In such a situation, the legal qualification of IP rights as investments raised the real possibility that the host state could be re-

43 ICSID Case No. ARB/00/2, Mihaly International Corporation v. Democratic Socialist Republic of Sri Lanka, Award, para. 60.

44 ICSID Case No. ARB/00/1, Zhinvali Development Ltd. v. Republic of Georgia, Award, para. 377; ICSID Case No. ARB/02/5, PSEG v. Turkey, Decision on Jurisdiction, paras. 66-73; ICSID Case No. ARB/00/9, Generation Ukraine, Inc. v. Ukraine, Award, paras. 8.6, 18.5-18.9.

45 See: C. Schreuer, L. Malintoppi, A. Reinisch and A. Sinclair, 135, 136; R. Hornick, "The Mihaly Arbitration: Pre-Investment Expenditure as a Basis for ICSID Jurisdiction", Journal of International Arbitration 2(20)/2003, 189.

46 See: ICSID Case No.ARB/10/7, Phillip Morris v. Uruguay, Decision on Jurisdiction, paras. 183, 234-236. 
stricted in amending relevant market regulation and, as a consequence of the introduced regulatory measures, held responsible for causing damages to the IP right holder and obliged to compensate the same. ${ }^{47}$

Additionally, in the Eli Lilly v. Canada case, which also appears to be relevant, unsatisfied with the altered legal standards regarding the acquisition of patents in the host state, the claimant commenced the first intellectual property investment dispute under the North America Free Trade Agreement (NAFTA). ${ }^{48}$ The claimant argued that the patent protection standards were inconsistent with the same standards of the other NAFTA members and a Canadian patent law at the time when it submitted the patent applications. ${ }^{49}$ Under the claimant's case, the rejection of the patent applications amounted to indirect expropriation of its intellectual property rights and contravened its legitimate expectations in relation to its investments in the amount of USD 500 million. ${ }^{50}$ This case has also confirmed that the legal qualification of IP rights as an investment could result in the international liability of the host state and compensation of damages caused by the state breaching the standards of legal protection (including expropriation and fair and equitable treatment).

The analysis of investment case law reveals various approaches and different legal standards of protection being claimed by IP right holders in order to protect their investments (IP rights) within international investment law. Fair and equitable treatment, protection against expropriation, national treatment, full protection and security and are just some of the available standards of protection. ${ }^{51}$ All these specific standards create different advantages and, at some point, even obstacles for IP rights holders to protect their investments in practice, which makes it even harder to predict all the possible consequences of the legal qualification.

Even though in both the cases analysed above the arbitral tribunals rendered in favour of the host state,${ }^{52}$ the fact that the IP rights could be

47 With regard to trademark protection, a similar case was initiated in 2006 when the claimant stated that the BIT was breached and his trademarks expropriated. For further details see: ICSID Case No. ARB/06/14, Shell v. Nicaragua; L. Liberti, "Intellectual Property Rights in International Investment Agreements - An Overview", OECD Working Papers on International Investment 2010/01, OECD Publishing.

48 UNCTRAL Case No. UNCT/14/2, Eli Lilly and Company v. Government of Canada, Final Award, para. 480; R. Okediji, "Is Intellectual Property Investment? Eli Lilly V. Canada and the International Intellectual Property System", University of Pennsylvania Journal of International Law 4(35)/2014.

49 Eli Lilly v. Canada, Notice of Arbitration, para. 9.

50 Ibid., para. 4.

51 For further details see: A. Reinisch, Standards of Protection, Oxford University Press, New York 2008.

52 For further details see: Phillip Morris v. Uruguay, Award; Eli Lilly v. Canada, Award, paras. 478-480. 
qualified as an investment represents a starting point for the conclusion that the infringement of such rights might result in the liability of the host state. As the rights holders are now even more encouraged to initiate proceedings against the host states for the alleged breaches of standards of protection, guaranteed by relevant legal instruments, there is an indication that the state could also face several negative impacts stemming from the additional legal protection to IP rights holders, if not in a form of compensation, then at least in the form of an order to bear its own costs of arbitration. ${ }^{53}$

Since the current arbitration practice already expressed the view that IP rights are capable of being expropriated (in terms of relevant standards of protection within the BITs), ${ }^{54}$ we could expect further development of arbitral practice in this manner. We could also expect that such a development would raise new questions in terms of interpretation and application of legal standards in the context of IP rights being protected as an investment. That being said, it remains to be seen whether the development of arbitral practice will have any positive impact on the development of the legal framework and investment environment in Serbia.

\section{CONCLUDING REMARKS}

The Law on Investments has introduced numerous improvements when compared to the preceding Law on Foreign Investments. Explicit inclusion of IP rights in the definition of an investment sends a clear message to all potential investors and enables enhancement of the investment environment. However, the lack of additional requirements such as the transfer of funds, or contribution to the state's development, reveals room for further improvement.

Concerning the definition of investment, the applicable BITs in Serbia mainly contain similar solutions to those envisaged by the Law. Apart from the investors from France and Sweden, all other foreign investors (having the nationality of a country that has concluded a BIT with Serbia) might rely on a broad definition of the term investment, which explicitly includes IP rights. Moreover, some of the BITs in force even refer to goodwill, know-how and technical processes as investments and do not impose any additional requirements.

Unlike the Law and the BITs in force, the ICSID Convention does not explicitly include IP rights in the definition of investment. Still, due

53 In Eli Lilly v. Canada case, the host state had to finally incur part of its own costs of legal representation and assistance. For further details see Eli Lilly v. Canada, Award, paras. 474-478.

54 Phillip Morris v. Uruguay, Award, para. 274. 
to the established ICSID case law and legal doctrine, it could be concluded that IP rights may be qualified as investments. Nonetheless, the sole existence of such rights would probably not be sufficient to trigger the protection provided by the Convention. By establishing certain additional prerequisites, the case law and jurisprudence have effectively interpreted the definition of investment in a way to protect as investments only those IP rights involving some of the specifically determined forms of economic activity in the host country. Additionally, even if IP rights are qualified as an investment in a particular case, it does not mean that those rights are infringed in terms of the specific standards of legal protection provided by the host state. Consequently, further development of arbitral practice related to the interpretation and application of those legal standards could be of crucial importance for the effective legal protection of IP rights.

The observed discrepancy between nominal and effective legal protection of IP rights is strongly emphasized in Serbia due to the lack of the relevant domestic legal practice and concise legal definitions. The provided broad nominal protection of IP rights could enhance the domestic investment environment, however, at the same time, the lack of any proof of the effective legal protection could lead to deterioration and create a zero-sum game.

\section{REFERENCES}

Braga, C., Fink, C., "The Relationship between Intellectual Property Rights and Foreign Direct Investment", Duke Journal of Comparative \& International Law 9/1998.

Dolzer, R., Schreuer, C., Principles of International Investment Law, Oxford University Press, Oxford 2012.

Draškoci, V., "Problem preširoke definicije pojma investicije u dvostranim sporazumima o međusobnom podsticanju i zaštiti ulaganja između Srbije i stranih država", Pravo i privreda 5-8/2007.

Federico, M., Oriani, R., (eds.), The Economic Valuation of Patents: Methods and Applications, Edward Elgar Publishing, Cheltenham 2011.

Grabowski, A., "The Definition of Investment under the ICSID Convention: A Defense of Salini", Chicago Journal of International Law $15 / 2014$.

Hornick, R., "The Mihaly Arbitration: Pre-Investment Expenditure as a Basis for ICSID Jurisdiction", Journal of International Arbitration $2 / 2003$. 
Hosking, J., Perkams, M., "The Protection of Intellectual Property Rights Through International Investment Agreements: Only a Romance or True Love?", Transnational Dispute Management 2/2009.

Jovanović, M., Odgovornost države za zažtitu stranih direktnih ulaganja, doctoral dissertation, Pravni fakultet Univerziteta u Beogradu, Beograd 2014.

Jovanović, N., "Pravni režim stranih ulaganja u Srbiju kao banana državu", Pravo i privreda 4-6/2013.

Knežević, G., Pavić, V., Arbitraža i ADR, Pravni fakultet Univerziteta u Beogradu, Beograd 2013.

Liberti, L., "Intellectual Property Rights in International Investment Agreements - An Overview", OECD Working Papers on International Investment, OECD Publishing 01/2010.

Marković, S., Popović, D., Pravo intelektualne svojine, Pravni fakultet Univerziteta u Beogradu, Beograd 2013.

Maskus, E., "Intellectual Property Rights and Foreign Direct Investment", Centre for International Economic Studies, Working Paper 22/2000.

Okediji, R., "Is Intellectual Property Investment? Eli Lilly V. Canada and the International Intellectual Property System", University of Pennsylvania Journal of International Law 4/2014.

Pavić, V., "Odlučnim polukorakom napred - osvrt na Zakon o ulaganjima”, Anali Pravnog fakulteta u Beogradu 1/2016.

Posner, R., Landes, W., The Economic Structure of Intellectual Property Law, Harvard University Press, Cambridge, Massachusetts, London 2003.

Reinisch, A., Standards of Protection, Oxford University Press, New York 2008.

Russell, L., Smith, G., Intellectual Property: Valuation, Exploitation, and Infringement Damages, Wiley, Hoboken 2005.

Sasse, J., An Economic Analysis of Bilateral Investment Treaties, Springer, Hamburg 2011.

Schreuer, C., et al., The ICSID Convention: A commentary, Cambridge University Press, Cambridge 2009.

Stanivuković, M., "Rešavanje sporova koji proističu iz stranih ulaganja", Pravni život 12/1997.

Stauder, D., von Mühlendahl, A., "Territorial Intellectual Property Rights in a Global Economy", MPI Studies on Intellectual Property, Competition and Tax Law, Springer, Berlin 2009.

Subedi S., International Investment Law, Hart Publishing, Oxford 2008. 
Vanhonnaeker, L., Intellectual Property Rights as Foreign Direct Investments - from Collision to Collaboration, Edward Elgar Publishing, Cheltenham 2015.

Weil, D., Economic Growth, Pearson Education, Harlow 2013.

Welfens, P., Macro Innovation Dynamics and the Golden Age: New Insights into Schumpeterian Dynamics, Inequality and Economic Growth, Springer International Publishing, Cham 2017.

Article history: Received: 30. 9. 2017. Accepted: 29. 12. 2017. 